\title{
Evaluation of disposable filtration systems for harvesting high cell density fed batch processes
}

\author{
Antje Pegel, Friedemann Übele, Sven Reiser, Dethardt Müller, Gregor Dudziak \\ From 22nd European Society for Animal Cell Technology (ESACT) Meeting on Cell Based Technologies \\ Vienna, Austria. 15-18 May 2011
}

\section{Introduction}

In the underlying study we evaluated different single-use filtration systems for cell separation and harvest clarification in 1,000 L scale. A screening of different depth filters was carried out with various single-use filters from Pall, Cuno (3M), Millipore and Sartorius Stedim. In total, we included 85 depth filtrations in the screening. Out of that, two single-use filtration systems were chosen and further tested in $200 \mathrm{~L}$ scale. Based on these results, a single-use filtration set-up for harvesting production scale fed batch processes was determined.

\section{Material and methods}

High cell density fed batch cultivations of a monoclonal antibody (mAb) expressing Chinese Hamster Ovary $(\mathrm{CHO})$ cell line were harvested by depth filtration and

Table 1 Characteristics of the different single-use depth filters

\begin{tabular}{|c|c|c|c|c|}
\hline Manufacturer & Material* & Filter type & Retention range $(\mu \mathrm{m})^{*}$ & Number of filter layers* \\
\hline & & PDK7 & $20-4$ & \\
\hline & & PDK6 & $20-3$ & \\
\hline \multirow[t]{3}{*}{$\begin{array}{l}\text { Pall } \\
\text { Seitz }^{\circledR} \text { HP-Series }\end{array}$} & $\begin{array}{l}\text { Cellulose, } \\
\text { Diatomaceous earth, } \\
\text { Resin }\end{array}$ & PDK5 & $20-1$ & 2 \\
\hline & & $\mathrm{PDH} 4$ & $15-0.4$ & \\
\hline & & PDE2 & $3.5-0.2$ & \\
\hline \multirow[t]{2}{*}{$\underline{\text { Seitz }}{ }^{\circledR}$ P-Series } & & KS50P & $0.8-0.4$ & 1 \\
\hline & & 10SP02A & $7-1$ & \\
\hline \multirow[t]{3}{*}{$\begin{array}{l}\text { Cuno } \\
\text { Zeta Plus }{ }^{\circledR}\end{array}$} & $\begin{array}{l}\text { Cellulose, } \\
\text { Diatomaceous earth, } \\
\text { Perlite }\end{array}$ & 30SP02A & $5-0.8$ & 2 \\
\hline & & 60SP02A & $5-0.65$ & \\
\hline & & 60ZA05A & $0.8-0.6$ & \\
\hline \multirow[t]{2}{*}{$\begin{array}{l}\text { Millipore } \\
\text { Millistak+ }{ }^{\circledR}\end{array}$} & $\begin{array}{l}\text { Cellulose, } \\
\text { Diatomaceous earth }\end{array}$ & $\mathrm{DOHC}$ & $9-0.6$ & 2 \\
\hline & & $\mathrm{COHC}$ & $2-0.2$ & \\
\hline \multirow[t]{2}{*}{$\begin{array}{l}\text { Sartorius } \\
\text { Sartoclear } P^{\circledR}\end{array}$} & $\begin{array}{l}\text { Cellulose, } \\
\text { Diatomaceous earth, } \\
\text { Binding matrix }\end{array}$ & PB1 & $11-4$ & 2 \\
\hline & & PB2 & $8-1$ & \\
\hline
\end{tabular}

* Data according to manufacturers [http://www.pall.com, http://www.cuno.com, http://www.millipore.com, http://www.sartorius-stedim.com].

\footnotetext{
* Correspondence: antje.pegel@rentschler.de

Rentschler Biotechnologie GmbH, 88471 Laupheim, Germany
} 


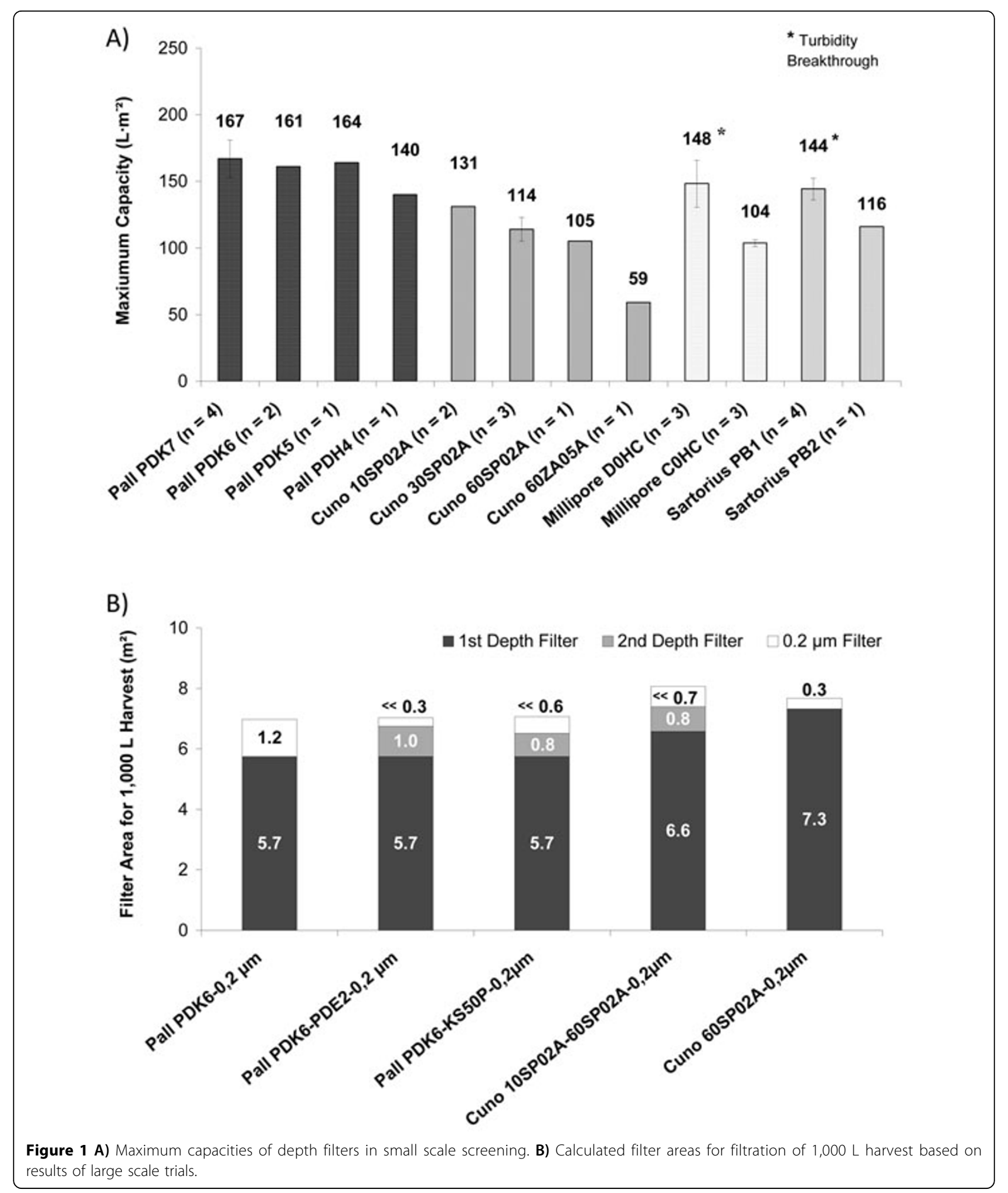

$0.2 \mu \mathrm{m}$ filtration after 14 to 19 days at viabilities ranging from 40 to $95 \%$. For the screening in $10 \mathrm{~L}$ scale, singleuse depth filters $\left(23\right.$ to $\left.26 \mathrm{~cm}^{2}\right)$ with different separation ranges were used (Table 1). Subsequently, two disposable depth filtration systems were tested in $200 \mathrm{~L}$ scale using filter capsules with a filter area of 0.23 to $0.25 \mathrm{~m}^{2}$. Depth filtrates were $0.2 \mu \mathrm{m}$ filtered with Pall EKV $\left(20 \mathrm{~cm}^{2}\right)$. During filtration, a constant flow of 100 
$\mathrm{L} \cdot \mathrm{m}^{-2} \cdot \mathrm{h}^{-1}$ was applied. Maximum capacities of the filters were determined at a pressure of 1 bar. Filter performance was assessed with regard to filter capacity, filtrate turbidity and product yield. Furthermore, content of DNA and Host Cell Protein (HCP) in filtrates were measured.

\section{Results}

\section{Depth filter screening}

The filters PDK7, PDK6 and PDK5 from Pall showed the highest maximum capacities with $161-167 \mathrm{~L} / \mathrm{m}^{2}$ (Figure $1 \mathrm{~A}$ ). These double layered filters had identical first membranes and differing finer second membranes. Filtrate turbidity was below 7 NTU when applying PDK6, whereas in filtrates generated with the coarser filter PDK7 turbidities up to 9 NTU were observed. Additionally, product loss with PDK6 (6 \%) was lower compared with PDK7 (8\%) or PDK5 (13\%). For that reason Pall PDK6 was selected for the scale-up experiments.

Additionally, the depth filters 10SP02A and 60SP02A from Cuno were chosen. For filter 10SP02A a maximum capacity of $131 \mathrm{~L} / \mathrm{m}^{2}$ was obtained. However, the filtrate turbidity was higher than 10 NTU causing a fast blocking of the $0.2 \mu \mathrm{m}$ filter. Therefore, this filter was combined with the finer depth filter 60SP02A. The filter 60SP02A was selected due to turbidity values below 10 NTU and an acceptable capacity of $105 \mathrm{~L} / \mathrm{m}^{2}$ when applied stand-alone.

Turbidity breakthroughs at pressures below 1 bar were observed for the depth filters Millipore D0CH and Sartorius Stedim PB1 (Figure $1 \mathrm{~A}$ ). Consequently, these filters were not considered for the scale-up studies.

\section{Scale-up}

The selected depth filters were applied in $200 \mathrm{~L}$ scale using the Stax ${ }^{\mathrm{TM}}$ Disposable Depth Filter System (Pall) and the Zeta Plus ${ }^{\mathrm{TM}}$ Encapsulated System (Cuno), respectively. Performance of depth filters was comparable in large scale and small scale. Maximum capacities in the large scale trials were $174 \mathrm{~L} / \mathrm{m}^{2}$ for Pall PDK6, $152 \mathrm{~L} / \mathrm{m}^{2}$ for Cuno 10SP02A, and $137 \mathrm{~L} / \mathrm{m}^{2}$ for Cuno 60SP02A. Product loss was below $10 \%$.

Based on maximum capacities filter areas were calculated for harvest in 1,000 L scale (Figure $1 \mathrm{~B}$ ). An optimal filtration set-up leading to the lowest total filter area $\left(6.9 \mathrm{~m}^{2}\right)$ was found in the depth filter Pall PDK6 and a subsequent $0.2 \mu \mathrm{m}$ filter. Insertion of a second depth filter after Pall PDK6 reduced the area of the 0.2 $\mu \mathrm{m}$ filter but did not affect the total filter area. The depth filter area of Cuno 60SP02A $\left(7.3 \mathrm{~m}^{2}\right)$ was comparable to that of the filter combination Cuno 10SP02A - 60SP02A $\left(7.4 \mathrm{~m}^{2}\right)$.
DNA content in the filtrate was reduced by $30 \%$ with Pall PDK6 and even by $70 \%$ with the additional depth filter PDE2. The Cuno depth filter combination 10SP02A - 60SP02A reduced DNA content by $99 \%$ compared to $90 \%$ when only applying 60SP02A. With the Pall depth filters a reduction of HCP by $30 \%$ was measured whereas no HCP removal was observed for the Cuno depth filters.

\section{Conclusion}

In this concept study disposable filtration systems were successfully tested in terms of identifying suitable filtration set-ups for equipping a 1,000 L disposable manufacturing line. These single-use filtration systems can thereby replace conventional (stainless steel) disc centrifuge and filtration steps in industrial mammalian cell culture production processes. The $\mathrm{Stax}^{\mathrm{TM}}$ system from Pall equipped with the filter PDK6 followed by a $0.2 \mu \mathrm{m}$ filtration was identified as the first choice single-use filtration set-up offering high capacities and a low product loss. Addition of a finer second depth filter can further increase filtrate clarification resulting in a reduction of DNA and HCP in filtrates and a smaller area of the subsequent $0.2 \mu \mathrm{m}$ filter, but is also combined with a higher risk of product loss and an increased time and handling effort.

\section{Acknowledgement}

We thank Novartis Pharma AG for supporting this project.

Published: 22 November 2011

doi:10.1186/1753-6561-5-S8-P73

Cite this article as: Pegel et al:: Evaluation of disposable filtration systems for harvesting high cell density fed batch processes. BMC Proceedings 2011 5(Suppl 8):P73.

Submit your next manuscript to BioMed Central and take full advantage of:

- Convenient online submission

- Thorough peer review

- No space constraints or color figure charges

- Immediate publication on acceptance

- Inclusion in PubMed, CAS, Scopus and Google Scholar

- Research which is freely available for redistribution 